\title{
触 New Disease Reports \\ Diplodia species associated with dieback of Retama raetam in Tunisia
}

\author{
S. Hlaiem ${ }^{1,2}$, M. Zouaoui Boutiti ${ }^{1}$ and M.L. Ben Jamaa ${ }^{1}$ \\ ${ }^{1}$ Institute National of Research Rural Engineering, Water and Forests, B.P.N ${ }^{\circ} 10,2080$, Ariana, Tunisia. ; ${ }^{2}$ National \\ Agronomic Institute of Tunisia ,43 Avenue Charles Nicolle 1082, Tunis, Tunisia \\ *E-mail: sawssenhlaiem@gmail.com
}

Received: 23 Jul 2019. Published: 30 Dec 2019. Keywords: identification, necrosis, pathogen

Retama raetam is a shrub native to North Africa and is considered a medicinal plant due to its anti-microbial activity. There are a very few reports of diseases on $R$. raetam but in 2017, in the region of Bizerte (northern Tunisia) shrubs of $R$. raetam were seen with symptoms of dieback, including wilted twigs, necrosis and stem cankers.

To isolate the putative pathogen, 30 small pieces of infected stems and tissues were surface-sterilised with $3 \%$ sodium hypochlorite, washed in sterile distilled water, placed on potato dextrose agar (PDA) plates and incubated at $25^{\circ} \mathrm{C}$ for three days in darkness. Fungal colonies growing from the plant material were white fluffy mycelia becoming grey with age at $25^{\circ} \mathrm{C}$. Within one week of subculturing semi-immersed and superficial black pycnidia formed on sterilised pine needles, placed over actively growing cultures incubated in light. Conidia were first hyaline and then turned dark brown as they matured. They were aseptate with obtuse apex and truncate ends, measuring $22.9-30 \times 9.4-13.6 \mu \mathrm{m}$. Based on morphological and cultural characteristics, all isolates were identified as Diplodia sp. (Pérez et al., 2010). Molecular identification was performed by sequencing the rDNA ITS region (White et al., 1990), translationelongation factor $1 \alpha$ gene (Carbone \& Kohn 1999) and the $\beta$-tubulin genes (Glass \& Donaldson 1995). One isolate TN 80 was deposited to GenBank. BLAST searches of ITS (GenBank Accession No. MN123532), EF-1- $\alpha$ (MN125371) and $\beta$-tubulin (MN125372) sequences revealed 98\% (EU080927), 99\% (EU863181) and 99\% (MG015820) identity to Diplodia $s p$., respectively.

A pathogenicity test was done according to the method of inoculation of Linaldeddu et al. (2014) by inoculating the pathogen on five excised healthy $R$. raetam shoots (30 cm long). A mycelial plug $\left(3-4 \mathrm{~mm}^{2}\right)$ taken from the margin of an actively growing seven-day-old colony on PDA was placed in a shallow wound $(3 \mathrm{~mm})$ made by a scalpel on the middle of each shoot. Control shoots were inoculated with sterile PDA plugs only. The inoculated shoots were enclosed in a transparent plastic bag at room temperature $\left(20-26^{\circ} \mathrm{C}\right)$. Four weeks post inoculation all $R$. raetam shoots inoculated with Diplodia showed symptoms of tip blight that appeared as brownish to black necrotic lesions extending above and below the inoculation point, stem lesions measured $53 \quad \pm 5 \mathrm{~mm}$. The botryosphaeriaceous fungus was successfully re-isolated from the margin of the healthy and brown lesions of each of the inoculated replicate canes whereas control shoots remained symptomless thus fulfilling Koch's postulates.

Diplodia pseudoseriata was described from native Myrtaceae trees in Uruguay (Pérez et al., 2010). To our knowledge, this is the first report of Diplodia sp.causing shoot blight on Retama raetam in Tunisia.

\section{References}

1. Carbone I, Kohn LM, 1999. A method for designing primer sets for speciation studies in filamentous ascomycetes. Mycologia $\mathbf{9 1}$, 553-556. http://dx.doi.org/10.1080/00275514.1999.12061051

2. Glass NL, Donaldson GC, 1995. Development of primer sets designed for use with PCR to amplify conserved genes from filamentous Ascomycetes. Applied and Environmental Biology 61, 1323-1330.

3. Linaldeddu BT, Deidda A, Scanu B, Franceschini A, Serra S, BerrafTebbal A, Zouaoui Boutiti M, Ben Jemâa ML, Philips AJL, 2014. Diversity of Botryosphaeriaceae species associated with grapevine and other woody hosts in Italy, Algeria and Tunisia, with descriptions of Lasiodiplodia exigua and Lasiodiplodia mediterranea sp. nov. Fungal Diversity 71, 201-214. http://dx.doi.org/10.1007/s13225-014-0301-x

4. Pérez CA, Wingfield MJ, Slippers B, Altier NA, Blanchette RA, 2010. Endophytic and canker-associated

Botryosphaeriaceae occurring on non-native Eucalyptus and native Myrtaceae trees in Uruguay. Fungal Diversity 41, 53-69. http://dx.doi.org/10.1007/s13225-009-0014-8

5. White TJ, Bruns T, Lee S, Taylor J, 1990. Amplification and direct sequencing of fungal ribosomal RNA genes for phylogenetics. In: Innis MA, Gelfand DH, Sninsky JJ, White TJ, eds. PCR Protocols: A Guide to Methods and Applications. San Diego, CA, USA: Academic Press, 315-322. http://dx.doi.org/10.1016/B978-0-12-372180-8.50042-1

To cite this report: Hlaiem S, Zouaoui Boutiti M, Ben Jamaa ML, 2019. Diplodia species associated with dieback of Retama raetam in Tunisia. New Disease Reports 40, 21. http://dx.doi.org/10.5197/j.2044-0588.2019.040.021 